\title{
Targeting Bombesin Peptide Receptors for Cancer Imaging: Perspective in Prostate, Lung and Breast Cancer
}

ISSN: 2637-773X

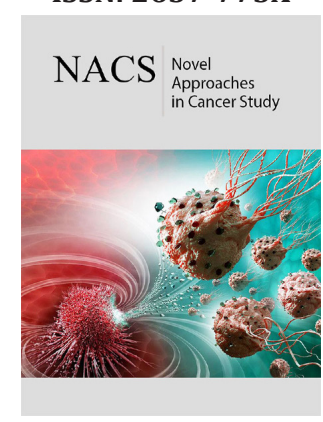

*Corresponding author: Raunak Varshney, Division of Cyclotron and Radiopharmaceutical Sciences, Delhi, India, 110054,

Email: raunak_varshney@yahoo.com, raunak@inmas.drdo.in

Submission: 㘹: August 25, 2020

Published: 眥 October 09, 2020

Volume 5 - Issue 3

How to cite this article: Raunak Varshney, Ajay Chitkara, Meenakshi Saklani, Amritjyot Kaur, Rashi Mathur et al. Targeting Bombesin Peptide Receptors for Cancer Imaging: Perspective in Prostate, Lung and Breast Cancer. Nov Appro in Can Study. 5(3). NACS.000611. 2020. DOI: 10.31031/NACS.2020.05.000611

Copyright@ Raunak Varshney, This article is distributed under the terms of the Creative Commons Attribution 4.0 International License, which permits unrestricted use and redistribution provided that the original author and source are credited.
Raunak Varshney ${ }^{*}$, Ajay Chitkara ${ }^{2}$, Meenakshi Saklanii,3, Amritjyot Kaur ${ }^{2}$, Rashi Mathur ${ }^{1}$, Anjani Tiwari ${ }^{3}$, Baljinder Singh ${ }^{2}$ and Anil K Mishra ${ }^{1}$

${ }^{1}$ Division of Cyclotron and Radiopharmaceutical Sciences, Institute of Nuclear Medicine and Allied Sciences, Delhi, India, 110054

${ }^{2}$ Postgraduate Institute of Medical Education and Research, Department of Nuclear Medicine, Chandigarh, India 160012

${ }^{3}$ Department of Chemistry, Babasaheb Bhimrao Ambedkar University, (A Central University), Vidya Vihar, Raebareli Road, Lucknow - 226025

\begin{abstract}
Peptides-coupled imaging agents are emerging as a new tool for early diagnosis with low adverse effects. Peptide-receptor based radiolabeled complex with good affinity to target specific receptors in cancers are required for imaging and quantification. Receptor mediated targeting of tumors for diagnosis, therapy or both is an encouraging approach and has increased remarkably over past 10-15 years. The attainment of these approaches related to selection of specific receptor for certain cancer type and their binding to the specific ligand. Receptor targeting radiopharmaceuticals are easy to synthesize and being small molecules, they exhibit excellent permeability, low immunogenicity, high specificity and minimum side effects. Gastrin-releasing three mammalian bombesin peptide receptors have shown great potential for cancer targeting because of their overexpression in various human malignancies. This review discusses the recent advances of bombesin receptors as potential targets for diagnosis using radiolabel bombesin analogues in prostate, lung, and breast cancer.
\end{abstract}

Keywords: Bombesin; Cancer; Gastrin-releasing peptide; Prostate cancer; Breast cancer; Lung cancer

Abbreviations: BN: Bombesin; CT:Computed Tomography; ${ }^{64} \mathrm{Cu}$ : Copper-64; ${ }^{18} \mathrm{~F}$ : Fluorine-18; GRPR: Gastrin-Releasing Peptide Receptor; ${ }^{6} \mathrm{Ga}$ : Gallium-68;HER 2: Human Epidermal Growth Factor Receptor Type 2; ${ }^{111}$ In: Indium-111; ${ }^{177}$ Lu: Lutetium-177; NMB:Neuromedin B Receptor; PET: Positron Emission Tomography; PSMA: Prostate-Specific Membrane Antigen; SPECT: Single Photon Emission Computed Tomography; SUV Max: Maximum Standardized Uptake Value; ${ }^{99} \mathrm{mTc}$ : Technetium-99m; ${ }^{90} \mathrm{Y}$ : Yttrium-90

\section{Introduction}

One of the main reasons for focus on these particular cancer as prostate and breast cancers are the most common types cancer in men and women respectively. However small and non-small cell lung cancer are most frequent in both. The molecular basis for the utility of radiopeptides is due to their peptide receptor over expression by certain tumours [1]. Peptides are more important elements in fundamental biological processes due to their specificity for controlling various biological functions through their specific receptors naturally. The increased attention for peptides or their receptors for imaging cancer is due to their expression/over expression in many primary human cancers and their ability to target specific receptor. The clinical impact of radiolabelled peptides has been observed in theranostics by diagnosis of location of tumours and their metastases by receptor scintigraphy and by facilitating receptor radiotherapy of tumours for treatment. However, the research on peptide based radioligand seems to be slight aperture in the huge oncological area, but the receptor targeting by short peptide of over expressed receptors in tumours has become very important for cancer imaging [2].

The most common radio peptide analogues are the somatostatin derivative and some of these derivatives have become commercially available, FDA approved drugs [2,3]. Some of them such as, ${ }^{111}$ In-DTPA-OctreoScanP $® P$, which binds to somatostatin receptor for the diagnosis of neuroendocrine tumours. ${ }^{99 \mathrm{~m}} \mathrm{Tc}$-analogue is known as NeoTect which expressed better specificity for lung cancer diagnosis. Octreotide and its analogues labelled with ${ }^{111}$ In, ${ }^{90} \mathrm{Y},{ }^{64} \mathrm{Cu}$ or ${ }^{177} \mathrm{Lu}$ are under study for the treatment of patients and present promising results $[2,4,5]$. All the mentioned studied have paved the path in the development of radiolabelled 
peptides for theranostic application in oncology. Many research groups are captivated to design and develop radiolabelled bombesin (BN) analogues as Bn peptide have proved better affinity for gastrin releasing peptide (GRP) receptors along with their over expression in many types of human cancer [6-8].

\section{Bombesin Receptors}

A vital tetradecapeptide, Bombesin $(\mathrm{Bn})$ was sequestered from the skin of two European marine toads which belongs to the Bombina toridae, Bombina bombina and Bombina variegate family. The rare name of this peptide family was originated from the names of the frogs or toads. However, the authentic novel amidated tetradecapeptide was isolated from the European frog Bombina bombina $[9,10]$. Subsequently many similar peptides were reported and divided into three groups as per their modification in the particular amino acids (Table 1).

Table 1: Bombesin and related peptide groups.

\begin{tabular}{|c|c|c|}
\hline S. No & Name of the Peptide (-COOH Terminus) & Structure of Peptide Group \\
\hline & Bombesin & pGlu-Gln-Arg-Leu-Gly-Asn-Gln-Trp-Ala-Val-Gly-His-Leu-Met-NH ${ }_{2}$ \\
\hline 1 & Bombesin Peptide & Gly-His-Leu-Met-NH ${ }_{2}$ \\
\hline 2 & Ranatesin-litorin Peptide & Gly-His-Phe-Met- $\mathrm{NH}_{2}$ \\
\hline 3 & Phyllolitorin Peptide & Gly-Ser-Phe/Leu-Met-NH ${ }_{2}[9,11,12]$ \\
\hline
\end{tabular}

Bombesin receptors are $\mathrm{G}$ protein-coupled receptors which are comprised of three mammalian BB1, BB2, and BB3 subtype receptors [11-14]. The BB1 often known as the neuromedin $B$ receptor (NMBR) and the mammalian ligand for this receptor is neuromedin $\mathrm{B}(\mathrm{NMB})$ which was initially recognized in porcine spinal cord. In 10-mer peptide sequence of NMB, 6 of the $7 \mathrm{COOH}$ terminal amino acids resembles with litorin. The NMB helps in various physiological actions like immune defence, thyroid, swallowing, regulation of weight and cognition etc $[15,16]$. Overexpression of NMB is similarly observed in several neoplasms i.e. prostrate, lung, breast, pancreas, colon etc [8].

Gastrin-releasing peptide receptor (GRPR) is a BB2 subtype and the mammalian ligand for this receptor is Gastrin-releasing peptide (GRP) [12]. McDonald et al. [17] in 1979 found that GRP is 27 amino acids peptide and having similarity with C-terminal amino acid with bombesin. GRP also work as an endocrine cancer cell-growth factor for both normal tissues and cancer cells and boosts many physiological actions like exocrine secretion and smooth muscle contraction. BB2 receptors have shown their overexpression in various human cancers i.e. breast, prostate, lung, central nervous system especially gliomas \& meningiomas, ovarian, pancreatic cancers and neuroblastomas $[6,18,19]$. The affinity of BB1 towards NMB is seen to be 100 -fold higher than towards GRP. On the other hand, the affinity of BB2 receptor towards GRP is found to be 50fold higher than towards NMB [20,21].

A subtype of G protein coupled receptor having similar structure with bombesin-receptor (BnR) subtype is human bombesinreceptor subtype-3 (BRS-3). BRS-3 is having 51\% amino acid similarity of the GRPR and its $47 \%$ of the amino-acid is identical with the NMBR [12,22]. However, Mantey et al. [23] and Pradhan et al. [24] described that [D-Tyr6, Ala11, Phe13, Nle14] bombesin is a efficacious ligand with similarity for BB3 and found to be over expressed in various cancers which vary from prostrate, lung and neuroendocrine etc. Reubi et al. [8], Schulz et al. [25] and Jenson RT et al. [12] enlightened that the BRS-3 have a restricted distribution than the GRP and NMB receptors. However, the BRS-3 is particularly expressed in GI tract along with CNS and peripheral tissues. BRS3, NMB-R, and GRP-R have shown expression in a various human tumors and cancer cell lines at different grades $[8,26]$. NMB is of great interest as expressed by a various type of cancers due to their capacity to generate tumour cell proliferation $[27,28]$. However, GRPR subtype is more important due to its higher expression density as compare to NMBR and BRS-3. In terms of peptide, being a small regulatory peptide $\mathrm{Bn}$ has high cellular permeability and bio compatibility because of which it is seen to a better targeting molecule. Moreover, Bn can also be integrated with nanoparticles to increase surface density (peptides per nanoparticle) due to its nano size and does not influence the properties of the nanoconjugation $[1,29]$.

\section{Bombesin Receptors Role in Multiple Cancers}

\section{Bombesin receptors and prostate cancer}

Prostate-cancer generally shows over-expression of BnRs in contrast to benign, prostatic hyperplasia and normal prostate. In various studies of primary prostate cancer (PCa), there is over expression of GRPR 62-100 \% along with NMBR, BRS-3 existence atypical (0-20\%), 50-85\% in lymph node and osseous metastases from PC [8,30-32]. The decline expression of GRPR has been expressed in advanced androgen-independent stages of $\mathrm{PC}$ in few studies and effect is more prominent mainly in bone metastases $[30,31]$. There are several studies examining the likelihood of imaging prostate cancer with different BnR-analogues in humans [33-46].

In the first human trial of ${ }^{68} \mathrm{Ga}-\mathrm{BAY}$ 86-7548 that includes 5 volunteers, the excretory route was found to be urinary system (absorbed dose $=0.61 \mathrm{mSv} / \mathrm{MBq}$ ), the second organ absorbing highest dose was pancreas (absorbed dose $=0.51 \mathrm{mSv} / \mathrm{MBq}$ and overall effective dose was $0.051 \mathrm{mSv} / \mathrm{MBq}$ [33]. Similarly, two other radiopharmaceuticals: ${ }^{68} \mathrm{Ga}-$ NOTA- RM26 and ${ }^{68} \mathrm{Ga}$ - NODAGA- MJ9 ( ${ }^{68} \mathrm{Ga}$ - NODAGA- 4- amino 1 carboxymethylpiperidine-bombesin analogue) showed the same organ biodistribution $[34,35]$. Kahkonen et al. [36] reported that PET/ 
CT of ${ }^{68} \mathrm{Ga}$ - BAY 86-7548 before surgery in PCa indicates PET accuracy of $83 \%$ with almost similar or higher sensitivity (89\%) and specificity (81\%). The highest uptake was reported in PCa tumour site when compared with normal and benign prostate hyperplasia. Similar results were lately reported by Touijer et al. [37] who also concluded that no connection was observed in GRPR and prostate-specific membrane antigen (PSMA) expression using immunohistochemistry.

The role of ${ }^{18} \mathrm{~F}$ and ${ }^{64} \mathrm{Cu}$ tagged antagonist were also assessed in a small study of PCa patients. In a study of 4 patients, ${ }^{64} \mathrm{Cu}$ labelled antagonist $\left({ }^{64} \mathrm{Cu}-\mathrm{CB}-\mathrm{TE} 2 \mathrm{~A}-\mathrm{AR} 06\right)$ role was evaluated in recently diagnosed cases of PCa [38]; Labelling GRPR antagonists with ${ }^{64} \mathrm{Cu}$ not only had high tumour to background ratio but also had high image contrast, longer half-life which is important parameter for dosimetry calculations. In a comparative study of ${ }^{18} \mathrm{~F}-\mathrm{BAY} 864367$ with ${ }^{18} \mathrm{~F}$-fluorocholine, the usefulness of ${ }^{18} \mathrm{~F}$-BAY derivative in human study of 10 patients with biopsy confirmed PCa were evaluated. The PET/CT of ${ }^{18} \mathrm{~F}$-BAY 864367 showed positive tumour lesion in 5 out of 10 patients. However, the combination of both along with histopathology experiment accurately indicates prostate lesions for 5 negative scans [39]. In breast and prostate cancer with advanced disseminated disease positive scan was depicted in only about $50 \%$ patients using radiolabelled GRPR antagonist SB3 (DOTA-paminomethylaniline-diglycolic acid-D-Phe-Gln-Trp-AlaVal-Gly-His-Leu-NHEt) [40].

${ }^{68} \mathrm{Ga}$-RM2 ((DOTA-4-amino-1-carboxymethyl-piperidine-DPhe-GlnTrp-Ala-Val-Gly-His-Sta-Leu- $\mathrm{NH}_{2}$ ) and ${ }^{68} \mathrm{Ga}$-PSMA PET was comparatively studied by Minamimoto et al. [41]. They evaluated the physiological and abnormal uptake of ${ }^{68} \mathrm{Ga}-\mathrm{RM} 2$. The clearance route of ${ }^{68} \mathrm{Ga}$-RM2 was found to be kidneys with the highest uptake in pancreas while ${ }^{68} \mathrm{Ga}$-PSMA-11 had urinary excretory route, with highest salivary uptake alongwith GI and hepatobiliary uptake. Nock et al. [42] reported the biologic profile of modified ${ }^{67} \mathrm{Ga}-,{ }^{177} \mathrm{Lu}$ , and ${ }^{111}$ In-NeoBOMB1 based radioligands, in-vitro studies by GRPRpositive cells and in-vivo by mouse models. All three radioligand indicate high binding affinity $\left(\mathrm{IC}_{50}=1-2 \mathrm{nM}\right)$ and good metabolic stability in peripheral mouse blood $(>95 \%$ intact at 5 min after injection). High GRPR-specific uptake in the PC-3 xenografts after injection was also observed.

In a review study of $18 \mathrm{~F}$-fluoroethylcholine PET/CT with 16 repeated prostate cancer patients had given negative and inconclusive results. Wieser et al. [43] compared it with ${ }^{68} \mathrm{Ga}$ RM2. PET/CT of ${ }^{68} \mathrm{Ga}-\mathrm{RM} 2$ exhibited uncommon uptake in 10 patients/16 patients. In the two patients multiple bone lesions and additional lymph nodes in the pelvis was noted with indecisive ${ }^{18}$ Ffluoroethylcholine PET/CT. The raised PSA levels during the scan of ${ }^{68} \mathrm{Ga}$ RM2 PET/CT $(5.5 \mathrm{ng} / \mathrm{ml})$ then at $18 \mathrm{~F}$-fluoroethylcholine $\mathrm{PET} / \mathrm{CT}(2.4 \mathrm{ng} / \mathrm{ml})$ requires confirmation with large cohort of patients. Minamimoto et al. [44] enrolled patients with biochemical relapse and negative CT, MRI and ${ }^{99} \mathrm{Tc}-\mathrm{MDP}$ scan. Out of 32 patients enrolled in the study, 23 patients were identified as recurrent prostate cancer by ${ }^{68} \mathrm{Ga}-\mathrm{RM} 2$. The detection rate was found to be
$71.8 \%$ which indicates the potential of ${ }^{68} \mathrm{Ga}-\mathrm{RM} 2$ in biochemical relapse of prostate cancer.

Zhang et al. [35] included 17 newly diagnosed patients and 11 post therapy patients of prostate cancer in the study. ${ }^{68} \mathrm{Ga}$-RM26 $\mathrm{PET} / \mathrm{CT}$ detected all 11 patients with biochemical recurrence and $15 / 17$ newly diagnosed patients were also positive in ${ }^{68} \mathrm{Ga}$-RM26 PET/CT. ${ }^{68}$ Ga-bombesin PET/CT, (GRPR agonist) were performed on 22 patients, but it detected less primary tumours, lymph nodes, and bone metastases than ${ }^{68} \mathrm{Ga}$-RM26 (GRPR antagonist).

A prospective study in 95 patient having biochemical recurrent prostate cancer was treated with ${ }^{68} \mathrm{Ga}$-RM2 PET/MRI observed the highest uptake in urinary bladder, which indicate the complex was excreted through urinary route [45]. Pancreas was the organ with the highest uptake followed by intense uptake in GI tract. Mild to moderate uptake was also observed in stomach, duodenum and rectum. In another study (15 patients) of biopsy confirmed prostate cancer, correlation of PET scan before surgery and histopathology were presented. They found no correlation in region based and whole prostate SUV max with histopathology and postoperative T category [46].

\section{Theragnostic studies}

Kurth et al. [47] performed first human dosimetry of ${ }^{177} \mathrm{Lu}$ labelled GRPR antagonist in 4 patients (mean activity $=4.48 \pm 0.9 \mathrm{GBq}$ ) with metastatic castration-resilient prostate cancer. According to RADAR dosimetry scheme and based on quantitative SPECT/CT, absorbed doses for different organs along with tumour lesions were considered. The mean absorbed dose was highest in pancreas $(1.08 \pm 0.44 \mathrm{~Gy} / \mathrm{GBq})$ as suggested by diagnostic studies. Tumour lesion received mean dose of $6.20 \pm 3.00 \mathrm{~Gy} / \mathrm{GBq}$ [47]. Similar to PSMA ligand studies, the bone marrow shows low uptake with ${ }^{177} \mathrm{Lu}$-RM2 [48]. In case of kidneys, ${ }^{177} \mathrm{Lu}-\mathrm{RM} 2$ showed a low absorbed dose as compared to that of ${ }^{177} \mathrm{Lu}-\mathrm{PSMA}-617$ [48] or ${ }^{177} \mathrm{Lu}-$ DOTA-TATE [49].

GRPR-targeted radiopharmaceuticals are effective radiotracers for prostate cancer assessment, indicating a higher rate of detection; they are also reliable for metastatic foci evaluation. These initial reports are encouraging but further study is required to find out the association of GRPR \& advanced hormone-resistant prostatic tumours expression.

\section{Bombesin receptors in lung Cancer}

Lung cancer has shown a significant association in growing understanding of Bn-related peptides and BnR's essential roles in cancer development, differentiation, and for future diagnosis. Lung cancer regularly express bombesin receptors and the main reason is that the small-cell-lung-cancers (SCLC) develop and secrete Bnlike-peptides [28,50]. In SCLC cancers, 52-100 percent expresses GRPR, 55 percent NMBR, 25 percent BRS-3. However in non-smallcell lung cancer (NSCLC) cells, 62-78 percent expresses GRPR, 68 percent NMBR, 8 percent BRS-3, and in bronchial carcinoids, 0-100 percent expresses GRPR, 4-88 percent NMBR, 35-88 percent BRS-3 
$[12,8,51]$. There is increased, stimulus for growth and proliferation as well as increased adhesion when Bombesin receptors were activated on lung cancer subtypes [28,50,52]. The higher expression of GRPR is mostly observed in the patients having advanced stage of lung cancer [51]. However, limited study to image/target lung cancer cells over expressing bombesin receptors is available. The use of BnR-labelled probes to diagnose lung-cancers in humans is still under research. In another study ${ }^{99 \mathrm{~m}} \mathrm{Tc}$ radiolabelled multimeric receptor targeting probe using RGD tripeptide to target $\alpha_{v} \beta_{3}$-integrins and bombesin receptor-agonist was used. The probe indicated higher uptake for the possibility to image the lung cancer cell metastasis in-vivo by targeting multiple receptors [53]. In another study ${ }^{99 \mathrm{~m}} \mathrm{Tc}$-labelled-GRPR-agonist imaging resulted in high tumour to background ratio in lung cancer xenograft nude mice model, suggesting this might be good imaging methodology for NSCLC [54].

Mattei et al. [51] stated that in case of advanced-stage lung disease the expression GRP receptors was found to be more prevalent and a strong correlation between the stage of lung cancer and GRPR expression was observed. Comparison of GRPR expression in a small cell and non-small cell lung cancer shows almost similar results; however, the GRP-receptor expression has increased intensity in non-small cell lung cancer.

BRS-3-receptor is also known as bombesin receptor due to their structural homology. It is due to the fact that several studies have mentioned in lung cancer cells having growth properties in these cells. Moreno et al. [55] confirmed the prospective significance of orphan BRS-3 receptor. They have examined the incidence/comparative assessable manifestation of human BRS-3 and GRPR/NMBR receptor along with its effects for initiation on cell-signalling/progress in various human lung-cancer cell-lines. The findings indicate that human BRS-3, much like GRPR/NMBR, is frequently present at high levels $(62 \%)$ in lung cancer cells. These results indicate that BR-3 must be studied in detail like GRPR/ NMBR for the development of new treatment, diagnosis or both for lung cancer.

\section{Bombesin receptors and breast cancers}

Numerous studies show that in breast cancers, $38-96 \%$ is of GRPR and $0-50 \%$ is of NMBR, BRS-3 subtypes [8,25,56,57]. Many authors have extensively demonstrated overexpression of GRP receptors in breast cancer [8,56-59], explicitly in estrogen receptor expressing class cancers [60-62]. Many radiolabelled SPECT ${ }^{111}$ In, $\left.{ }^{99} \mathrm{mTc}\right)$ and PET $\left({ }^{64} \mathrm{Cu},{ }^{68} \mathrm{Ga},{ }^{18} \mathrm{~F}\right)$ BnR-agonists are predominately used for GRPR imaging. These agents bind to breast-cancer-cells and indicated good result both in cell line and animal models. Few authors have also carried out a comparative in vivo study using ${ }^{68} \mathrm{Ga}$-labelled-BnR-agonist and common PET-imaging agents on xenografts of breast cancer in nude-mice. The results indicated higher tumour-uptake in case of ${ }^{18} \mathrm{~F}$-FDG and ${ }^{68} \mathrm{Ga}$-labelled-BnRagonist than ${ }^{18} \mathrm{~F}$-FDG alone. Moreover, ${ }^{68} \mathrm{Ga}$-labelled-BnR-agonist showed tumoral changes as a result of tamoxifen treatment which were not obtained using ${ }^{18} \mathrm{~F}$-FDG. It was concluded that along with better tumour imaging, ${ }^{68} \mathrm{Ga}$-labelled-BnR-agonist also helped in hormonal-treatment response assessment in breast-cancer-cells which was not possible using ${ }^{18} \mathrm{~F}-\mathrm{FDG}$ [63-65].

Liu Z et al. [66] developed heterodimeric-PET-probes based on ${ }^{18} \mathrm{~F},{ }^{64} \mathrm{Cu}$ and ${ }^{68} \mathrm{Ga}$ radioisotope by conjugating the RGD sequence to target $\alpha_{v} \beta_{3}$-integrins and BnR-agonist. High-uptake of agonist and capability to image in xenografed nude-mice was observed. This conjugate permit to image breast-cancers not only with high expressing $\mathrm{Bn}$ receptor-but also low expressing $\alpha_{\mathrm{v}} \beta_{3}$-integrinreccptors due to dual receptor targeting. Iron-oxide nanoparticles conjugated BnR agonists were evaluated by Jafari et al. [67] and this specific contrast agent has high affinity for GRP receptor on breast cancer cell lines for MR-Imaging. Additionally, it has shown good diagnostic potential to localize breast cancer-in-vivo. Aranda Lara L et al. [68] evaluated a fused probe integrating a ${ }^{99 \mathrm{~m}} \mathrm{Tc}-\mathrm{BnR}$ agonist and folate-receptor to target constantly overexpressed receptors GRPR and folate $(F R \alpha)$ in breast cancer. It showed increased uptake both in in vitro and in vivo studies using breastcancer-cell line and breast-cancer-xenografts respectively. Heidari et al. [69] investigated the use of BnR-agonists conjugated to gold-nanoparticles/nano rods coated with polyethylene glycol as a potential nonionizing laser based-imaging-agent having higher affinity for GRPR expressing breast cancer cells. De Barros assessed ${ }^{99 m}$-Tc labelled-BnR-agonist conjugated with liposome which exhibited high-uptake and strong scintigraphic images of breastcancers [70,71]. Furthermore, Guojun W et al. [72] revealed that the development of MDA-MB-231-breast cancer cells was inhibited by a NMBR antagonist.

There are many clinical studies using radiolabelled BnR agonist probes in detecting, localizing and imaging breast lesions [7381]. In a study by Van de Wiele $C$ et al. [73] high specific tumourlocalization and better tumour imaging were observed in $4 / 6$ breast tumour patients using radiolabelled-BnR-agonist-ligand ( $\left.{ }^{99 \mathrm{~m}} \mathrm{Tc}-\mathrm{RP} 527\right)$. In other study they have evaluated nine clinically suspected breast cancer and four 4-tamoxifen-resistant osseous malignancies from breast-cancers [74]. In which the primary tumour uptake of ${ }^{99 \mathrm{~m}} \mathrm{Tc}-\mathrm{RP} 527$ was evident in 8 patients in a group of 9 patients and in case of tamoxifen-resistant patients no uptake of ${ }^{99 \mathrm{~m} T c-R P 527}$ was found.

A comparative study of ${ }^{99 \mathrm{~m}} \mathrm{Tc}-\mathrm{Bn}$ and ${ }^{99 \mathrm{~m}} \mathrm{Tc}$-alone in 3 breast cancer patients was reported by Scopinaro F et al. [75]. They have mentioned higher absorption in ${ }^{99 \mathrm{~m} T c-l a b e l l e d-B n}$ probe in the tumour than ${ }^{99 \mathrm{~m}} \mathrm{Tc}$. The lymph node metastases were also detected by ${ }^{99 \mathrm{~m}} \mathrm{Tc}$-labeled-Bn demonstrating potential use of this technique. Four breast cancer patients and seven healthy subjects were studied by Mendoza- Sanchez et al. [76] in the normal physiologic distribution of radiolabelled-BnR-agonist (99mTc-HYNIC-Lys3-Bn). The maximum uptake was observed in malignant tumour followed by lungs, pancreas and renal route of excretion; however, the least uptake is observed in bone marrow. In a consecutive study on 33 
suspected breast cancer patients by Shariati $\mathrm{F}$ et al. [77] using ${ }^{99 \mathrm{~m}} \mathrm{Tc}-\mathrm{Bn}$ imaging indicates $100 \%$ sensitivity, $60 \%$ specificity and $100 \%$ negative predictive value. Similarly, ${ }^{99 \mathrm{~m} T c-R G D-B n}$ and ${ }^{99 \mathrm{~m} T c-}$ 3P4-RGD2 was reported for detection of breast cancer lesions in 6 female patients by Chen et al. [78]. The results indicate five malignant lesions with distinct uptake and in one case uptake was not distinctive. The four malignant cases have shown integrin and GRPR expression, one case indicated GRPR positive (integrin $\alpha_{v} \beta_{3}=$ -ve) while one case was integrin $\left(\alpha_{v} \beta_{3}\right)$ positive (GRPR negative).

Ji T et al. [79] compared the results of ultrasound and ${ }^{99 \mathrm{~m}} \mathrm{Tc}-$ RGD-Bn to locate the tumour. Due to the dual receptor targeting sensitivity of ${ }^{99 m}$ Tc-RGD-Bn SPECT/CT was observed 93.5\% and $82 \%$ than ultrasound respectively. A similar specificity (79\%) and positive predictive value was obtained for ${ }^{99 m}$ Tc-RGD-Bn SPECT/ CT as well as for ultrasound. In case of lymph node metastases,

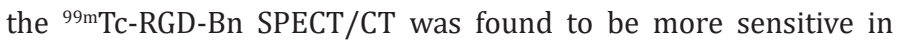
detecting lesions greater than $10 \mathrm{~mm}$. However, with increased sensitivity ${ }^{99 \mathrm{~m} T c-R G D-B B N}$ has ability for identifying breast lesions but still its role is complementary to ultrasound.

Stoykow et al. [80] conducted a study to investigate the use of ${ }^{68} \mathrm{Ga}$-RM2 in fifteen diagnosed breast cancer patients. ${ }^{68} \mathrm{Ga}$-complex clearly identified thirteen lesions out of total eighteen along with five false-negative results.ER and PR expression was exhibited by all cancers as seen on PET. Among the 5 cancers only one came out to be ER-positive and other not diagnosed by PET.

${ }^{68} \mathrm{Ga}-\mathrm{NOTA}-\mathrm{RM} 26$ PET/CT was studied by Zang et al. [81] and detected 29 primary tumours out of 34 tumours which were also validated histopathologically. The uptake value of five PET-negative tumours was less than or equivalent to the uptake value of normal breast tissue. Histopathological analysis proved the occurrence of lymph node metastases in eighteen, while PET was affirmative in fifteen patients. There was significant increase in the SUVmax in ERpositive tumours comparatively to negative tumours, in addition a positive correlation was observed with GRPR expression level. It was also found that the SUVmax were considerably greater in the secretory stage as compared to non-secretory stage or the postmenopausal stage. The sensitivity and specificity of 68Ga-complex appeared to increase in the patients showing ER-negative tumours, however the patients undertook the acquisition on their secretory stage were excluded from this study.

Morgat et al. [73] comparatively evaluated 68Ga-RM2 and 18F-FDG for precise uptake in tumour areas of breast cancer (14 samples) by using tissue micro imaging. They have also examined Ki-67, HER2, GRPR and immunohistochemistry analysis for ER and progesterone receptor (PR) in all the specimens. The authors observed higher specific binding of ${ }^{68} \mathrm{Ga}-\mathrm{RM} 2$ and lower of ${ }^{18} \mathrm{~F}-\mathrm{FDG}$ uptake in the ER- and PR-+ve type of cancer groups. However, the low-Ki-67 group of gallium derivative and high-Ki-67 group of ${ }^{18} \mathrm{~F}$-FDG has shown negligible difference in the prominence of HER2.They have observed that ${ }^{68} \mathrm{GaRM} 2$ gives higher binding in tumours independently indicating this gallium PET ligand could be corresponding to ${ }^{18} \mathrm{~F}$-FDG in ER-positive bearing tumours with a small proliferation manifestation. For an overview of all bombesin analogues clinical studies see (Table-2).

Table 2: Bombesin conjugates in cancer imaging studies (Clinical Studies).

\begin{tabular}{|c|c|c|c|c|c|}
\hline S.No & Patients Studied & Bombesin Analog & Imaging Technique & Results & Year/Ref \\
\hline \multicolumn{6}{|c|}{ Prostate cancer } \\
\hline 1 & $\begin{array}{l}10 \text { Patients (Primary \& } \\
\text { Recurrence: } 5 \text { Each) }\end{array}$ & ${ }^{18} \mathrm{FBAY} 864367$ & PET/CT & 5 Patients showed tumour & 2015 [39] \\
\hline 2 & $\begin{array}{l}17 \text { Patients }(\text { EIGHT=Breast, } \\
\text { Nine }=\text { PC })\end{array}$ & $\begin{array}{c}{ }^{68} \mathrm{Ga}-\mathrm{SB} 3 \text { (DPhe6, LeuN- } \\
\text { HEt13] Bn }\end{array}$ & $\mathrm{PET} / \mathrm{CT}$ & $\begin{array}{l}4 \text { Patients indicating breast while } \\
\text { five Patients having prostate cancer } \\
\text { group exhibited pathological uptake. }\end{array}$ & $2016[40]$ \\
\hline 3 & 7 Patients & $\begin{array}{c}\text { Comparison of }{ }^{68} \mathrm{Ga}-\mathrm{RM} 2 \\
\&^{68} \mathrm{Ga}-\mathrm{PSMA}\end{array}$ & $\mathrm{PET} / \mathrm{CT}$ & $\begin{array}{l}45 \text { altered metastatic lesions were } \\
\text { observed with }{ }^{68} \mathrm{Ga}-\mathrm{PSMA} \text { positive } \\
\text { and } 43 \text { with }{ }^{68} \mathrm{Ga}-\mathrm{RM} 2 .\end{array}$ & $2016[41]$ \\
\hline 4 & $\begin{array}{l}4 \text { patients with prostate } \\
\text { adenocarcinoma }\end{array}$ & ${ }^{68} \mathrm{Ga}-\mathrm{NeoBOMB} 1$ & PET/CT & $\begin{array}{c}\text { Promptly localized in pathologic } \\
\text { lesions, attaining high-contrast } \\
\text { imaging }\end{array}$ & $2017[42]$ \\
\hline 5 & $\begin{array}{l}16 \text { patients with BCR Pros- } \\
\text { tate cancer and negative } \\
{ }^{18} \mathrm{FECH}\end{array}$ & ${ }^{68} \mathrm{Ga}-\mathrm{RM} 2$ & $\mathrm{PET} / \mathrm{CT}$ & $\begin{array}{l}{ }^{68} \mathrm{Ga} \text {-Complex revealed minimum one } \\
\text { region with focal pathological uptake } \\
\text { in } 10 / 16 \text { patients }\end{array}$ & 2017 [43] \\
\hline 6 & $\begin{array}{l}5 \text { prostate cancer patients } \\
\text { with BCR for dosimetry }\end{array}$ & ${ }^{68} \mathrm{Ga}-N O D A G A-M J 9$ & $\mathrm{PET} / \mathrm{CT}$ & $\begin{array}{l}\text { Pancreas received the highest dose } \\
\text { followed by urinary bladder wall, } \\
\text { intestine and kidney. }\end{array}$ & 2018 [34] \\
\hline 7 & $\begin{array}{l}28 \text { Patients (17 newly diag- } \\
\text { nosed \& } 11 \text { post therapy) }\end{array}$ & $\begin{array}{l}\text { Antagonist }{ }^{68} \mathrm{Ga}-\mathrm{RM} 2 \mathrm{Do}- \\
\text { simetry and comparison } \\
\text { with agonist }{ }^{68} \mathrm{Ga}-\mathrm{BBN}\end{array}$ & $\mathrm{PET} / \mathrm{CT}$ & $\begin{array}{c}\text { It detects both primary prostate } \\
\text { cancer and metastasis \& estimated } \\
\text { to be superior GRPR agonist imaging } \\
\text { marker. }\end{array}$ & 2018 [35] \\
\hline
\end{tabular}




\begin{tabular}{|c|c|c|c|c|c|}
\hline 8 & $\begin{array}{l}32 \text { patients with BCR Pros- } \\
\text { tate cancer }\end{array}$ & $\begin{array}{l}{ }^{68} \text { Ga-labelled DOTA-4-ami- } \\
\text { no-1-carboxymeth- } \\
\text { yl-piperidine-bombesin(- } \\
{ }^{68} \text { Ga-RM2) }\end{array}$ & $\mathrm{PET} / \mathrm{CT}$ & $\begin{array}{l}\text { PET identified recurrent PCa in } 23 \\
\text { participants with detection rate of } \\
71.8 \%\end{array}$ & $2018[44]$ \\
\hline 9 & $\begin{array}{l}84 \text { patients (men) with } \\
\text { BCR PC }\end{array}$ & ${ }^{68} \mathrm{Ga}-\mathrm{RM} 2$ & PET/CT & $\begin{array}{c}\text { PET recognition rate was } 70.2 \% \\
\text { and recognized persistent PC in } 59 \\
\text { participants }\end{array}$ & 2019 [45] \\
\hline 10 & $\begin{array}{l}15 \text { Primary prostate cancer } \\
\text { patients }\end{array}$ & ${ }^{68} \mathrm{Ga}-\mathrm{RM} 2$ & $\mathrm{PET} / \mathrm{CT}$ & $\begin{array}{l}\text { Minimum one edge of increased } \\
\text { uptake of mentioned radioligand } \\
\text { related to a tumour manifestation } \\
\text { was found in } 14 \text { patients }\end{array}$ & 2019 [46] \\
\hline 11 & $\begin{array}{l}16 \text { prostate cancerpa- } \\
\text { tientsproved after biopsy }\end{array}$ & ${ }^{68} \mathrm{Ga}-\mathrm{RM} 2$ & $\begin{array}{l}\text { PET/CT imaging in } \\
\text { comparison with mpMRI, } \\
\text { Histopathology and IHC }\end{array}$ & $\begin{array}{l}\text { The sensitivity, specificity and accu- } \\
\text { racy of }{ }^{68} \mathrm{Ga}-\mathrm{RM} 2 \text { was } 85.2 \%, 81.3 \% \\
\text { and } 83.9 \% \text { respectively }\end{array}$ & 2019 [37] \\
\hline 12 & $\begin{array}{l}4 \text { patients with metastatic } \\
\text { castration-resilient PC }\end{array}$ & ${ }^{177} \mathrm{Lu}-\mathrm{RM} 2$ & SPECT/CT & $\begin{array}{l}\text { Improved uptake in tumour lesions } \\
\text { (mean absorbed dose }=6.20 \pm \\
\text { 3.00Gy/GBq.) and the pancreas } \\
\text { (mean absorbed dose }=1.08 \pm \\
0.44 \mathrm{~Gy} / \mathrm{GBq} \text { ) was observed }\end{array}$ & 2020 [47] \\
\hline \multicolumn{6}{|c|}{ Breast cancer } \\
\hline 13 & 6 patients & $\begin{array}{l}{ }^{99 \mathrm{~m}} \mathrm{Tc} \text { RGD-Bn and }{ }^{99 \mathrm{~m}} \mathrm{Tc}- \\
\text { RGD2 }\end{array}$ & SPECT/CT imaging & $\begin{array}{l}\text { All palpable malignant lesions were } \\
\text { spotted by both radiolabelled ligand }\end{array}$ & 2015 [78] \\
\hline 14 & 126 patients & ${ }^{99 \mathrm{~m}} \mathrm{Tc}$ RGD-Bn & $\begin{array}{l}\text { Comparison of SPECT/CT } \\
\& \text { ultrasound }\end{array}$ & $\begin{array}{l}{ }^{99 m} \mathrm{mc}-\text { RGD-Complex indicates high } \\
\text { sensitivity, specificity, PPV, NPV and } \\
\text { accuracy as compared to ultrasound }\end{array}$ & 2015 [79] \\
\hline 15 & $\begin{array}{c}15 \text { female patients with pri- } \\
\text { mary Breast cancer proved } \\
\text { after biopsy ( } 3 \text { bilateral } \\
\text { cancers) }\end{array}$ & ${ }^{68} \mathrm{Ga}-\mathrm{RM} 2$ & $\mathrm{PET} / \mathrm{CT}$ & $\begin{array}{l}13 \text { patients in this group validated } \\
\text { improved tumour uptake as com- } \\
\text { pared to normal breast tissue }\end{array}$ & 2016 [80] \\
\hline 16 & 35 female patients & $\begin{array}{l}{ }^{68} \text { Ga-NOTA-RM26(D-Phe- } \\
\text { Gln-Trp-Ala-Val-Gly-His- } \\
\text { Sta-Leu- } \mathrm{NH}_{2} \text { ) }\end{array}$ & $\mathrm{PET} / \mathrm{CT}$ & $\begin{array}{l}\text { Positive correlation was found be- } \\
\text { tween radiolabelled complex }\end{array}$ & 2018 [81] \\
\hline
\end{tabular}

In conclusion a strong correlation was observed in expression of GRPR in breast cancer cells showing ER-positive tumours. This shows high potential for development of GRPR antagonist for both diagnostic and therapeutic usage.

\section{Conclusion}

Prostate, Breast and Lung Cancers are the frequent cause of death worldwide. It is important to identify innovative and successful therapeutic methods for both early diagnosis and treatment. The over expression of various bombesin receptors in these cancers directs to advanced novel approaches for imaging as well as selective delivery of therapeutic agents. We have deliberated the role of bombesin peptide receptors in cancer imaging that could offer novel pathways to cancer diagnosis and treatment as widespread occurrence of BnR over expression in the mentioned cancer type. Several preclinical studies in animal models and recent human studies (especially breast / prostate cancer) the over-expression of these bombesin receptors showed promising results for theranostic. However, to better understand the bombesin receptors expression and to be considered as the potential perspective for diagnosis and therapy, large prospective clinical trials will be required.

\section{Acknowledgement}

The author thanks Director INMAS, DRDO.

\section{Conflict of Interest}

There is no Conflict of interest to declare.

\section{References}

1. Reubi JC (2003) Peptide receptors as molecular targets for cancer diagnosis and therapy. Endocrine Reviews 24(1): 389-427. 
2. Okarvi SM (2004) Peptide-based radiopharmaceuticals: Future tools for diagnostic imaging of cancers and other diseases. Medicinal Research Reviews 24(3): 357-397.

3. Nicolas G, Giovacchini G, Müller-Brand J, Forrer F (2011) Targeted radiotherapy with radiolabeled somatostatin analogs. Endocrinology and Metabolism Clinics of North America 40(1): 187-204.

4. Heppeler A, Froidevaux S, Eberle AN, Maecke HR (2000) Receptor targeting for tumor localisation and therapy with radiopeptides. Curr Med Chem 7(9): 971-994.

5. Mikołajczak R, Maecke HR (2016) Radiopharmaceuticals for somatostatin receptor imaging. Nuclear Medicine Review 19(2): 126132.

6. Moreno P, Ramos-Álvarez I, Moody TW, Jensen RT (2016) Bombesin related peptides/receptors and their promising therapeutic roles in cancer imaging, targeting and treatment. Expert Opinion on Therapeutic Targets 20(9): 1055-1073.

7. Hoffman TJ, Quinn TP, Volkert WA (2001) Radiometallated receptor-avid peptide conjugates for specific in vivo targeting of cancer cells. Nucl Med Biol 28(5): 527-539.

8. Reubi JC, Wenger S, Schmuckli-Maurer J, Schaer JC, Gugger M (2002) Bombesin receptor subtypes in human cancers: Detection with the universal radioligand ${ }_{(125)} \mathrm{I}_{-}\left[\mathrm{D}-\mathrm{TYR} \mathrm{(}_{(6)}\right.$, beta-ALA $\left.{ }_{(11)}, \quad \mathrm{PHE}_{(13)}, \quad \mathrm{NLE}_{(14)}\right]$ bombesin $_{(6-14)}$. Clin Cancer Res 8(4): 1139-1146.

9. Erspamer V, Gf E, M I (1970) Some pharmacological actions of alytesin and bombesin. J Pharm Pharmacol 22(11): 875-876.

10. Anastasi A, Erspamer V, Bucci M (1971) Isolation and structure of bombesin and alytesin, two analogous active peptides from the skin of the european amphibians bombina and alytes. Experientia 27(2): 166167.

11. Erspamer V (1988) Discovery, isolation, and characterization of bombesin-like peptides. Ann N Y Acad Sci 547: 3-9.

12. Jensen RT, Battey JF, Spindel ER, Benya RV (2008) International union of pharmacology. LXVIII. Mammalian bombesin receptors: Nomenclature, distribution, pharmacology, signaling, and functions in normal and disease states. Pharmacol Rev 60(1): 1-42.

13. Alexander SPH, Benson HE, Faccenda E, Pawson AJ, Sharman JL, Spedding M, et al. (2013) The concise guide to pharmacology 2013/14: G proteincoupled receptors: G protein-coupled receptors. Br J Pharmacol 170: 1459-1581.

14. Ramos-Álvarez I, Moreno P, Mantey SA, Nakamura T, Nuche-Berenguer B, Moody TW, et al. (2015) Insights into bombesin receptors and ligands: Highlighting recent advances. Peptides 72: 128-144.

15. Matusiak D, Glover S, Nathaniel R, Matkowskyj K, Yang J, et al. (2005) Neuromedin B and its receptor are mitogens in both normal and malignant epithelial cells lining the colon. American Journal of Physiology-Gastrointestinal and Liver Physiology 288(4): G718-G728.

16. Minamino N, Kangawa K, Matsuo H (1983) Neuromedin B: A novel bombesin-like peptide identified in porcine spinal cord. Biochemical and Biophysical Research Communications 114(2): 541-548.

17. McDonald TJ, Jörnvall H, Nilsson G, Vagne M, Ghatei M, et al. (1979) Characterization of a gastrin releasing peptide from porcine non-antral gastric tissue. Biochemical and Biophysical Research Communications 90(1): 227-233.

18. Moody TW, Mantey SA, Pradhan TK, Schumann M, Nakagawa T, et al. (2004) Development of high affinity camptothecin-bombesin conjugates that have targeted cytotoxicity for bombesin receptor-containing tumor cells. J Biol Chem 279(22): 23580-23589.
19. Pu F, Qiao J, Xue S (2015) GRPR-targeted protein contrast agents for molecular imaging of receptor expression in cancers by MRI. Sci Rep $5: 16214$.

20. Fleischmann A, Waser B, Gebbers JO, Reubi JC (2005) Gastrin-releasing peptide receptors in normal and neoplastic human uterus: involvement of multiple tissue compartments. The Journal of Clinical Endocrinology \& Metabolism 90(8): 4722-4729.

21. Varvarigou A, Bouziotis P, Zikos C, Scopinaro F, De Vincentis G (2004) Gastrin-Releasing Peptide (GRP) analogues for cancer imaging. Cancer Biotherapy and Radiopharmaceuticals 19(2): 219-229.

22. Moreno P, Mantey SA, Nuche-Berenguer B, Reitman ML, González N, et al. (2013) Comparative pharmacology of bombesin receptor subtype-3, nonpeptide agonist MK-5046, a universal peptide agonist, and peptide antagonist bantag-1 for human bombesin receptors. J Pharmacol Exp Ther 347(1): 100-116.

23. Mantey SA, Weber HC, Sainz E, Akeson M, Ryan RR, et al. (1997) Discovery of a high affinity radioligand for the human orphan receptor bombesin receptor subtype 3 , which demonstrates that it has a unique pharmacology compared with other mammalian bombesin receptors. J Biol Chem 272(41): 26062-26071.

24. Pradhan TK, Katsuno T, Taylor JE, Kim SH, Ryan RR, et al. (1998) Identification of a unique ligand which has high affinity for all four bombesin receptor subtypes. European Journal of Pharmacology 343(23): 275-287.

25. Schulz S, Röcken C, Schulz S (2006) Immunohistochemical detection of bombesin receptor subtypes GRP-R and BRS-3 in human tumors using novel antipeptide antibodies. Virchows Arch 449(4): 421-427.

26. Cornelio DB, Roesler R, Schwartsmann G (2007) Gastrin-releasing peptide receptor as a molecular target in experimental anticancer therapy. Ann Oncol 18(9): 1457-1466.

27. Yeğen BC (2003) Bombesin-like peptides: Candidates as diagnostic and therapeutic tools. Curr Pharm Des 9(12): 1013-1022.

28. Moody TW, Chan D, Fahrenkrug J, Jensen RT (2003) Neuropeptides as autocrine growth factors in cancer cells. Curr Pharm Des 9(6): 495-509.

29. Wang M, Thanou M (2010) Targeting nanoparticles to cancer. Pharmacological Research 62(2): 90-99.

30. Markwalder R, Reubi JC (1999) Gastrin-releasing peptide receptors in the human prostate: Relation to neoplastic transformation. Cancer research 59(5): 1152-1159.

31. Beer M, Montani M, Gerhardt J, Wild PJ, Hany TF, et al. (2012) Profiling gastrin-releasing peptide receptor in prostate tissues: Clinical implications and molecular correlates: GRPR in Prostate Cancer. Prostate 72(3): 318-325.

32. Ischia J, Patel O, Bolton D, Shulkes A, Baldwin GS (2014) Expression and function of gastrin-releasing peptide (GRP) in normal and cancerous urological tissues: GRP and its receptor in urological tissues. BJU Int 113: 40-47.

33. Roivainen A, Kahkonen E, Luoto P, Borkowski S, Hofmann B, et al. (2013) Plasma pharmacokinetics, whole-body distribution, metabolism, and radiation dosimetry of 68ga bombesin antagonist BAY ${ }_{86-7548}$ in healthy men. Journal of Nuclear Medicine 54(6): 867-872.

34. Gnesin S, Cicone F, Mitsakis P, Vander Gucht A, Baechler S, et al. (2018) First in-human radiation dosimetry of the gastrin-releasing peptide (GRP) receptor antagonist ${ }^{68} \mathrm{Ga}-\mathrm{NODAGA}^{-M J}{ }_{9}$. EJNMMI Research 8(1): 108.

35. Zhang J, Niu G, Fan X, Lang L, Hou G, et al. (2018) PET using a GRPR antagonist ${ }^{68} \mathrm{Ga} \mathrm{RM}_{26}$ in healthy volunteers and prostate cancer patients. J Nucl Med 59(6): 922-928. 
36. Kahkonen E, Jambor I, Kemppainen J, Lehtio K, Gronroos TJ, et al. (2013) In vivo imaging of prostate cancer using $\left[{ }^{68} \mathrm{Ga}\right]$-labeled bombesin analog BAY86-7548. Clinical Cancer Research 19(19): 5434-5443.

37. Touijer KA, Michaud L, Alvarez HAV, Gopalan A, Kossatz S, et al. (2019) Prospective study of the radiolabeled GRPR antagonist BAY86-7548 for positron emission tomography/computed tomography imaging of newly diagnosed prostate cancer. European Urology Oncology 2(2): 166-173.

38. Wieser G, Mansi R, Grosu AL, Schultze-Seemann W, Dumont-Walter RA, et al. (2014) Positron Emission Tomography (PET) imaging of prostate cancer with a gastrin releasing peptide receptor antagonist - from Mice to Men. Theranostics 4(4): 412-419.

39. Sah BR, Burger IA, Schibli R, Friebe M, Dinkelborg L, et al. (2015) Dosimetry and first clinical evaluation of the new 18F-radiolabeled bombesin analogue BAY 864367 in patients with prostate cancer Journal of Nuclear Medicine 56(3): 372-378.

40. Maina T, Bergsma H, Kulkarni HR, Mueller D, Charalambidis D, et al (2016) Preclinical and first clinical experience with the gastrin-releasing peptide receptor-antagonist $\left.{ }^{68}{ }^{\mathrm{Ga}}\right] \mathrm{SB}_{3}$ and PET/CT. Eur J Nucl Med Mol Imaging 43(5): 964-973.

41. Minamimoto R, Hancock S, Schneider B, Chin FT, Jamali M, et al. (2016) Pilot comparison of ${ }^{68} \mathrm{Ga}-\mathrm{RM}_{2}$ PET and ${ }^{68} \mathrm{Ga}$-PSMA- ${ }_{11}$ PET in patients with biochemically recurrent prostate cancer. Journal of Nuclear Medicine 57(4): 557-562.

42. Nock BA, Kaloudi A, Lymperis E, Giarika A, Kulkarni HR, et al. (2017) Theranostic perspectives in prostate cancer with the gastrin-releasing peptide receptor antagonist NeoBOMB1: preclinical and first clinical results. J Nucl Med 58(1): 75-80.

43. Wieser G, Popp I, Christian Rischke H, Drendel V, Grosu AL, et al. (2017) Diagnosis of recurrent prostate cancer with PET/CT imaging using the gastrin-releasing peptide receptor antagonist ${ }^{68} \mathrm{Ga}-\mathrm{RM}_{2}$ : Preliminary results in patients with negative or inconclusive $\left[{ }^{18} \mathrm{~F}\right]$ FluoroethylcholinePET/CT. Eur J Nucl Med Mol Imaging 44(9): 1463-1472.

44. Minamimoto R, Sonni I, Hancock S, Vasanawala S, Loening A, et al. (2018) Prospective evaluation of ${ }^{68} \mathrm{Ga}-\mathrm{RM}_{2}$ PET/MRI in patients with biochemical recurrence of prostate cancer and negative findings on conventional imaging. J Nucl Med 59(5): 803-808.

45. Baratto L, Duan H, Harrison C, Hatami N, Aparici CM, et al. (2019) Preliminary results of a prospective study of ${ }^{68} \mathrm{Ga}-\mathrm{RM}_{2}$ PET/MRI for detection of recurrent prostate cancer in patients with negative conventional imaging. J Nucl Med 61(10): 650-650.

46. Fassbender TF, Schiller F, Mix M, Maecke HR, Kiefer S, et al. (2019) Accuracy of $\left[{ }^{68} \mathrm{Ga}\right] \mathrm{Ga}-\mathrm{RM}_{2}-\mathrm{PET} / \mathrm{CT}$ for diagnosis of primary prostate cancer compared to histopathology. Nuclear Medicine and Biology 70: 32-38.

47. Kurth J, Krause BJ, Schwarzenböck SM, Bergner C, Hakenberg OW, et al. (2020) First-in-human dosimetry of gastrin-releasing peptide receptor antagonist $\left[{ }^{177} \mathrm{Lu}\right] \mathrm{Lu}-\mathrm{RM}_{2}$ : A radiopharmaceutical for the treatment of metastatic castration-resistant prostate cancer. Eur J Nucl Med Mol Imaging 47(1): 123-135.

48. Delker A, Fendler WP, Kratochwil C (2016) Dosimetry for ${ }_{177}$ Lu-DKFZPSMA- $_{617}$ : A new radiopharmaceutical for the treatment of metastatic prostate cancer. Eur J Nucl Med Mol Imaging 43(1): 42-51.

49. Sandstrom M, Garske-Roman U, Granberg D, Johansson S, Widstrom C, et al. (2013) Individualized dosimetry of kidney and bone marrow in patients undergoing ${ }_{177} \mathrm{Lu}$-DOTA-octreotate treatment. Journal of Nuclear Medicine 54(1): 33-41.

50. Moody TW, Moreno P, Jensen RT (2015) Neuropeptides as lung cancer growth factors. Peptides 72: 106-111.

51. Mattei J, Achcar RD, Cano CH, Macedo BR, Meurer L, et al. (2014) Gastrin-releasing peptide receptor expression in lung cancer. Archives of Pathology \& Laboratory Medicine 138(1): 98-104.
52. Moody TW, Berna MJ, Mantey S, Sancho V, Ridnour L, et al. (2010) Neuromedin B receptors regulate EGF receptor tyrosine phosphorylation in lung cancer cells. European Journal of Pharmacology 637(1-3): 38-45.

53. Liu Z, Huang J, Dong C, Cui L, Jin X, et al. (2012) ${ }_{99} \mathrm{~m}$ Tc-Labeled RGDBBN peptide for small-animal SPECT/CT of lung carcinoma. Mol Pharmaceutics 9(5): 1409-1417.

54. Marostica L, de Barros AL, Silva J, Lopes S, Salgado B, et al. (2015) Feasibility study with ${ }^{99} \mathrm{mTc}$-HYNIC- $\beta$ Ala-Bombesin $\left({ }_{7-14}\right)$ as an agent to early visualization of lung tumour cells in nude mice. Nuclear Medicine Communications 37(4): 1.

55. Moreno P, Mantey SA, Lee SH, Ramos-Álvarez I, Moody TW, et al. (2018) A possible new target in lung-cancer cells: The orphan receptor, bombesin receptor subtype-3. Peptides 101: 213-226.

56. Dalm SU, Martens JWM, Sieuwerts AM, van Deurzen CHM, Koelewijn SJ, et al. (2015) In vitro and In vivo application of radiolabeled gastrinreleasing peptide receptor ligands in breast cancer. J Nucl Med 56(5): 752-757.

57. Gugger M, Reubi JC (1999) Gastrin-releasing peptide receptors in non-neoplastic and neoplastic human breast. The American Journal of Pathology 155(6): 2067-2076.

58. Reubi C, Gugger M, Waser B (2002) Co-expressed peptide receptors in breast cancer as a molecular basis for in vivo multireceptor tumour targeting. Eur J Nucl Med Mol Imaging 29(7): 855-862.

59. Bold RJ, Ishizuka J, Yao CZ, Townsend Jr CM, Thompson JC (1998) Bombesin stimulates in vitro growth of human breast cancer independent of estrogen receptors status. Anticancer Research 18(6A): 4051-4056.

60. Morgat C, Schollhammer R, Macgrogan G, Barthe N, Vélasco V, et al. (2019) Comparison of the binding of the gastrin-releasing peptide receptor (GRP-R) antagonist 68Ga-RM2 and 18F-FDG in breast cancer samples. PloS One 14(1): e0210905.

61. Morgat C, MacGrogan G, Brouste V, Vélasco V, Sévenet N, et al. (2017) Expression of gastrin-releasing peptide receptor in breast cancer and its association with pathologic, biologic, and clinical parameters: A study of 1,432 primary tumors. J Nucl Med 58(9): 1401-1407.

62. Dalm SU, Sieuwerts AM, Look MP, Melis M, van Deurzen CHM, et al. (2015) Clinical relevance of targeting the gastrin-releasing peptide receptor, somatostatin receptor 2 , or chemokine C-X-C motif receptor 4 in breast cancer for imaging and therapy. J Nucl Med 56(10): 1487-1493.

63. Ait-Mohand S, Fournier P, Dumulon-Perreault V, Kiefer GE, Jurek P, et al. (2011) Evaluation of ${ }_{64} \mathrm{Cu}$-labeled bifunctional chelate-bombesin conjugates. Bioconjugate Chemistry 22(8): 1729-1735.

64. Pujatti PB, Foster JM, Finucane C, Hudson CD, Burnet JC, et al. (2015) Evaluation and comparison of a new DOTA and DTPA-bombesin agonist in vitro and in vivo in low and high GRPR expressing prostate and breast tumor models. Applied Radiation and Isotopes 96: 91-101.

65. Retzloff LB, Heinzke L, Figureoa SD, Sublett SV, Ma L, Sieckman GL, et al. (2010) Evaluation of $\left[_{99} \mathrm{mTc}-(\mathrm{CO})_{3}\right.$-XY-bombesin $\left.\left.{ }_{7-14}\right) \mathrm{NH}_{2}\right]$ conjugates for targeting gastrin-releasing peptide receptors overexpressed on breast carcinoma. Anticancer Research 30(1): 19-30.

66. Liu Z, Yan Y, Liu S, Wang F, Chen X (2009) ${ }_{18} \mathrm{~F}_{64} \mathrm{Cu}$, and ${ }_{68}$ Ga labeled RGDbombesin heterodimeric peptides for PET imaging of breast cancer. Bioconjug Chem 20(5): 1016-1025.

67. Jafari A, Salouti M, Shayesteh SF, Heidari Z, Rajabi AB, et al. (2015) Synthesis and characterization of Bombesin-superparamagnetic iron oxide nanoparticles as a targeted contrast agent for imaging of breast cancer using MRI. Nanotechnology 26(7): 075101.

68. Aranda-Lara L, Ferro-Flores G, Ramírez F de M, Ocampo-García B, Santos-Cuevas C, et al. (2016) Improved radiopharmaceutical based on ${ }_{99} \mathrm{mTc}$-Bombesin-folate for breast tumour imaging. Nuclear Medicine Communications 37(4): 377-386. 
69. Heidari Z, Sariri R, Salouti M (2014) Gold nanorods-bombesin conjugate as a potential targeted imaging agent for detection of breast cancer Journal of Photochemistry and Photobiology B: Biology 130: 40-46.

70. de Barros ALB, Mota L das G, Soares DCF, de Souza CM, Cassali GD, et al. (2013) Long-circulating, pH-sensitive liposomes versus longcirculating, non-pH-sensitive liposomes as a delivery system for tumor identification. Journal of biomedical nanotechnology 9(9): 1636-1643.

71. de Barros ALB, Mota L das G, Coelho MMA, Corrêa NCR, de GóesAM, et al. (2015) Bombesin encapsulated in long-circulating pH-sensitive liposomes as a radiotracer for breast tumor identification. Journal of biomedical nanotechnology 11(2): 342-350.

72. Guojun W, Wei G, Kedong O, Yi H, Yanfei X, et al. (2008) A novel vaccine targeting gastrin-releasing peptide: Efficient inhibition of breast cancer growth in vivo. Endocrine-related cancer 15: 149-159.

73. Van de Wiele C, Dumont F, Vanden Broecke R, Oosterlinck W, Cocquyt $\mathrm{V}$, et al. (2000) Technetium- ${ }_{99} \mathrm{~m} \mathrm{RP}{ }_{527}$, a GRP analogue for visualisation of GRP receptor-expressing malignancies: A feasibility study. Eur J Nucl Med 27(11): 1694-1699.

74. Van de Wiele C, Phonteyne P, Pauwels P, Goethals I, Van den Broecke R, et al. (2008) Gastrin-releasing peptide receptor imaging in human breast carcinoma versus immunohistochemistry. Journal of Nuclear Medicine 49(2): 260-264.

75. Scopinaro F, Varvarigou A, Ussof W, De Vincentis G, Archimandritis S, et al. (2002) Breast cancer takes up ${ }_{99} \mathrm{mTc}$ bombesin. a preliminary report. Tumori Journal 88(3): S25-S28.
76. Mendoza-Sánchez AN, Ferro-Flores G, Ocampo-García BE, Morales-Avila E, Ramírez F de M, et al. (2010) Lys3-bombesin conjugated to ${ }^{99} \mathrm{mTc}$ labelled gold nanoparticles for in vivo gastrin releasing peptide-receptor imaging. J biomed Nanotechnol 6(4): 375-384.

77. Shariati F, Aryana K, Fattahi A, Forghani MN, Azarian A, et al. (2014) Diagnostic value of ${ }^{99} \mathrm{mTc}$-bombesin scintigraphy for differentiation of malignant from benign breast lesions: Nuclear Medicine Communications 35(6): 620-625.

78. Chen Q, Ma Q, Chen M, Chen B, Wen Q, et al. (2015) An exploratory study on ${ }^{99} \mathrm{mTc}$-RGD-BBN peptide scintimammography in the assessment of breast malignant lesions compared to ${ }^{99} \mathrm{mTc}_{3} \mathrm{P}_{4}-\mathrm{RGD}_{2}$. PLoS ONE 10(4): e0123401.

79. Ji T, Sun Y, Chen B, Ji B, Gao S (2015) The diagnostic role of ${ }^{99} \mathrm{mTc}$-dual receptor targeted probe and targeted peptide bombesin (RGD-BBN) SPET/CT in the detection of malignant and benign breast tumors and axillary lymph nodes compared to ultrasound. Hellenic Journal of Nuclear Medicine 18(2): 108-113.

80. Stoykow C, Erbes T, Maecke HR, Bulla S, Bartholomä M, et al. (2016) Gastrin-releasing peptide receptor imaging in breast cancer using the receptor antagonist ${ }^{68} \mathrm{Ga}_{-} \mathrm{RM}_{2}$ and PET. Theranostics 6(10): 1641.

81. Zang J, Mao F, Wang H, Zhang J, Liu Q, et al. (2018) 68Ga-NOTA-RM ${ }_{26}$ PET/CT in the evaluation of breast cancer: A pilot prospective study. Clinical Nuclear Medicine 43(9): 663-669. 